\title{
Bystroń evergreen
}

Joanna Tokarska-Bakir, Anna Zawadzka

Tworząc pismo, którego numer pierwszy oddajemy do rąk Czytelniczek i Czytelników, nawiązujemy do idei naukowych Jana Stanisława Bystronia, etnografa, autora Megalomanii narodowej. Chciałybyśmy, by stało się ono forum wymiany intelektualnej, przyciągającym teksty ważne i odważne, dla których w kurczącej się przestrzeni publicznej coraz trudniej znaleźć miejsce. Tym, czego zwłaszcza w niej brakuje, jest komunikacja pomiędzy poszczególnymi dziedzinami nauki, w szczególności zaś między etnografią, socjologią, literaturoznawstwem i filozofią z jednej, a historią z drugiej strony, oraz ukazywanie powiązań pomiędzy teorią i praktyką społeczną. Brak podobnej refleksji rzutuje na poziom polskiej debaty publicznej, spłycając ją, prowincjalizując i zatrzaskując w izolacji. Nasze pismo ma ambicję wypetnienia tej luki.

Temat numeru pierwszego to Fałszywe otwarcia, fatszywe zamknięcia. Stanowi on próbę dopowiedzenia i skomentowania wybranych dzieł naukowych, literackich i filmowych z ostatnich dwóch lat, które uważamy za szczególnie istotne, ponieważ na pozór mówią one to, czego dotąd w polskiej sferze publicznej powiedzieć nie było można. Interesuje nas, czy dzieła te rzeczywiście proponują nowe ramy dyskursu, a jeśli tak, to na jakich warunkach można w nim wziąć udział.

Publikowane przez nas eseje analizują te aspekty tekstów kultury, które inne media - nie tylko naukowe - pominęły lub potraktowały zdawkowo. Stąd w „Studia Litteraria et Historica" blok krytycznych recenzji Skrwawionych ziem Timothy Snydera - książki przedstawianej w Polsce jako przełom w studiach nad drugą wojną światową, za granicą, głównie w Niemczech, przyjmowanej z krytyczną rezerwą. W każdym numerze pisma pojawią się wywiady z czołowymi postaciami krajowej sceny naukowej, którym - nawiązując do Jana Stanisława Bystronia ${ }^{1}$ - zadawać będziemy pytanie o tematy dla polskiego humanisty „niemożliwe”. Rozpoczynamy od rozmów z Ireną Grudzińską-Gross i Jerzym Jedlickim. Stałą rubrykę stanowić będzie też historia mówiona, którą inicjuje poruszająca historia Krystyny Badurki. Historia mówiona to także wgląd w warsztat etnosocjologiczny: wywiady, które będziemy publikować, mają charakter ledwo zredagowanej transkrypcji. Tekstem Loïca Wacquanta chcemy rozpocząć cykl publikacji krążących wokół teorii Pierre’a Bourdieu i jej najbardziej współczesnych kontynuacji. Z kolei polemikę Piotra Sztompki i Michaela Burawoya, którą przedrukowujemy za pismem "Contemporary Sociology”, uważamy za wyraz ważnego pęknięcia dotychczasowego paradygmatu nauk społecznych oraz przejaw wpływu geopolitycznego usytuowania na sposób uprawiania socjologii.

1 W 1939 r. pisat: „co do dobrych rad, to przestałem się nimi przejmować; [...] o ile pamiętam - nie było chyba tematu, którego by mi z różnych stron nie odradzano" [Bystroń 1993: 5]. 
Chciałybyśmy, by za sprawą swojej interdyscyplinarności nasze pismo stało się głosem w dyskusji o stanie krajowej humanistyki. Decydując się wyłącznie na wersję internetową, stawiamy na powszechną dostępność, bo właśnie w barierach komunikacyjnych kryje się - naszym zdaniem - duże niebezpieczeństwo. Istotną przeszkodą jest niedofinansowanie humanistyki, z powodu którego musiałyśmy tymczasowo zrezygnować z idei, by pismo było w całości dwujęzyczne. Znacznie większą jednak - poszukiwanie intelektualnego bezpieczeństwa, które wyraża się we wzajemnej wrogości dyscyplin i środowisk, zamiast poszukiwania narzędzi uzgadniania języków i czerpania ze swoich dorobków. Nie sprzyja temu eliminowanie najostrzejszych kontrowersji poprzez ich utajnianie w anonimowych recenzjach. Aby tej praktyce przeciwdziałać, niektóre pisma amerykańskie, takie jak „Current Anthropology”, wprowadziły w latach osiemdziesiątych XX w. obyczaj publikowania recenzji bezpośrednio pod tekstami, o ile tylko te ostatnie spełniają standardy formalne. Reaktywując ${ }^{2}$ nasz rocznik, miałyśmy nadzieję przywrócić jawność recenzjom, szczególnie negatywnym. Ze względu na wymagania Ministerstwa Nauki i Szkolnictwa Wyższego stawiane pismom akademickim nie udało się nam na razie wprowadzić podobnego rozwiązania, będziemy jednak dążyć do niego w przyszłości.

\section{Bibliografia}

Bystroń Jan Stanisław, 1993, Komizm, Warszawa: TEXT; wyd. 1: Warszawa: Książnica i Atlas 1939.

2 „Studia Litteraria et Historica” jest twórczą kontynuacją pisma „Studia Litteraria Polono-Slavica” wydawanego przez Instytut Slawistyki PAN w latach 1993-2008. 